\title{
Spatial-Seasonal variations of Chlorophyllous biomass (Chlorophyll a) in the Upper Bandama basin of Ivory Coast
}

\author{
Tiéligounon Ali Soro ${ }^{1}$, Lozo Roméo N'Guessan ${ }^{1}$, Kouassi Blé Alexis Tardy ${ }^{2}$, Coulibaly Lacina ${ }^{3}$ and \\ Gooré Bi Gouli ${ }^{1}$
}

${ }^{1}$ Laboratory of Hydrobiology and Ecotechnology of Water, UFR Biosciences, Felix HouphouetBoigny University (Abidjan-Cocody, Ivory Coast), 22 BP 582 Abidjan 22, Ivory Coast

${ }^{2}$ Péléforo-Gbon-Coulibaly University (Korhogo, Ivory Coast)

${ }^{3}$ Sucaf-CI (Ferkessédougou, Ivory Coast

\begin{abstract}
The concentration of Chlorophyll was studied between October 2017 and September 2018 in the upper Bandama. It follows from our results that it is higher in the rainy season than in the dry season, especially during the full rainy season (FRS). This increase in the rainy season is linked to the runoff loaded with nutritious salt from the town of Ferkessédougou and various agrosystems in the region. The L2 and L3 stations of the Lokpoho River and M2 of the Bandama River are the most concentrated in chlorophyll. The Lokpoho River has the highest values of Chlorophyll compared to the Bandama River. This river should be monitored because of its high chlorophyll content which corroborates a rich high in nutrient salt.
\end{abstract}

Key Words: Bandama, River, Lokpoho, Chlorophyll, Variation.

\section{INTRODUCTION}

Phytoplankton is an essential component of the aquatic environment because it is the first link in the food chain. It's essential to aquatic life. However, its excess can be bad when the dominant species emits toxins or when the biomass reaches a level that can compromise the balance of the environment: it's the eutrophication [1]. The chlorophyllian pigment, which characterizes algae by enabling photosynthesis, is an indicator of phytoplankton biomass. Chlorophyll a is the most widely used biomass indicator for microscopic phytoplankton algae that inhabit the pelagic environment.

Regular monitoring of chlorophyll content provides a better understanding of the functioning of aquatic ecosystems [2]. In Upper Bandama, to our knowledge, there is no data on the chlorophyllous biomass of water. Thus, this study is a preliminary study to the annual variation of chlorophyll biomass in the Upper Bandama Basin, specifically in the main stream of the Bandama River and in the Lokpoho River, its second tributary of the left bank.

The objective of this study is to highlight the annual variation of chlorophyll a in the North Bandama River and in the Lokpoho River.

\section{MATERIAL AND METHODS}

\subsection{Field of study (Study site)}

The Bandama River Basin, entirely located in Ivory Coast, occupies an area of 97,500 km² between 3"50 and 7" W and 5 "and 10" $20 \mathrm{~N}$ [3]. Our study area is located in the upper Bandama basin in the region of Ferkessédougou and Korhogo (ex-savannah region). The sampling concerned the northern part of the Bandama Basin. This is the upper main course of the Bandama River to the Morrisson Dam (the first hydro-agricultural dam on the Bandama River) and its second main tributary of the left bank (the Lokpoho River) (Figure 1). The climate of this region is sub-humid tropical or sub-Sudanian transition [4], with two seasons: rainy 
season (June to September) and dry seasons (October to May). Note that from December to February, the region is liable to harmattan season, which is a hot dry wind from the Sahara. The average annual rainfall is 1200 mm, with an uni-modal regime centered in August-September, where 600 to $700 \mathrm{~mm}$ of rain are recorded (approximately 50 to $60 \%$ of the total annual rainfall) [5].

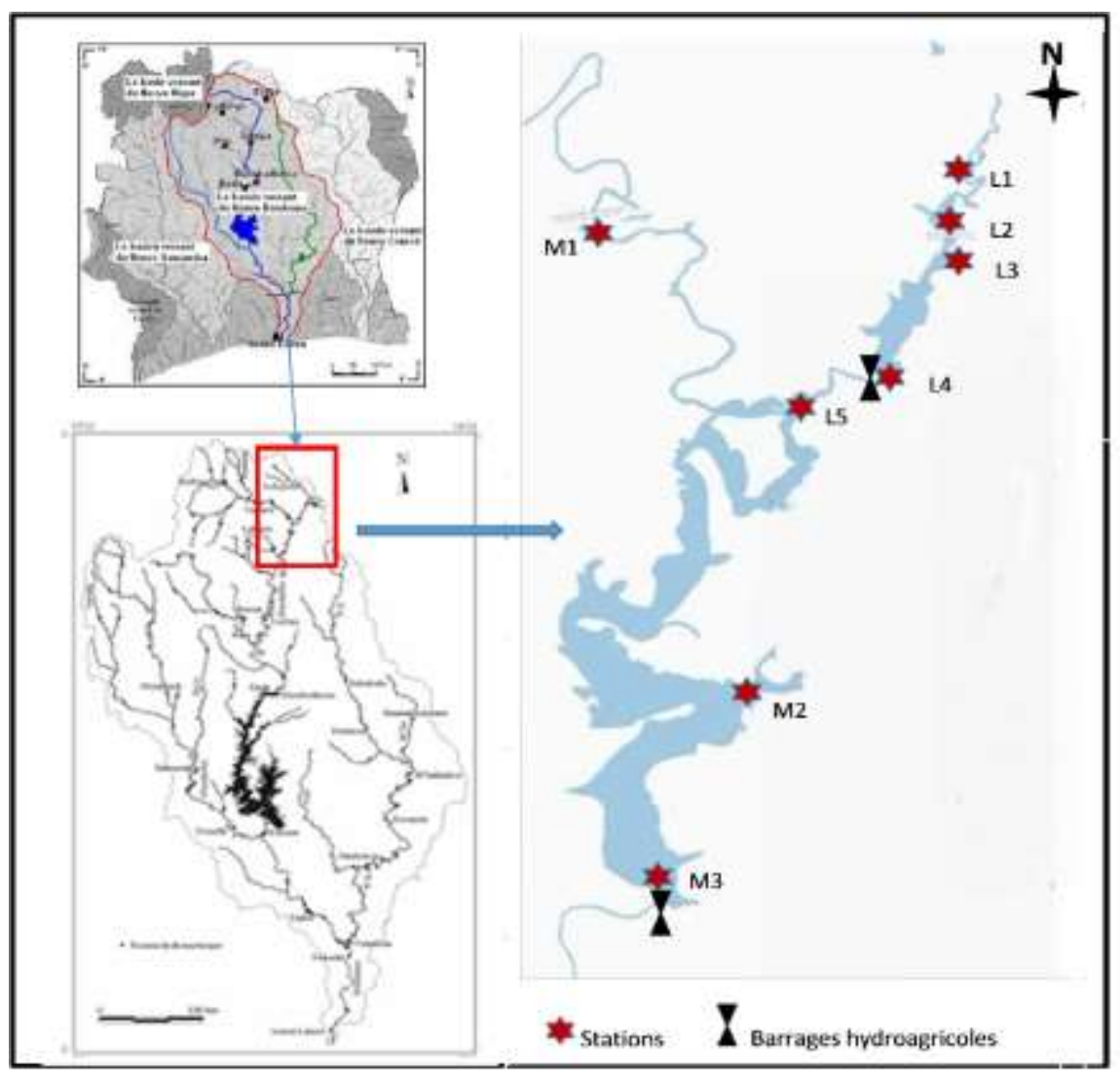

Figure 1: Hydrographic map of the northern part of the Bandama Basin (Upper Bandama and Lokpoho River in the Ferkessédougou region). L: Lokpoho River Stations; M: Bandama Stations (Morrisson Dam)

\subsection{Sampling, extraction and determination of chlorophyll a}

Chlorophyll sampling was carried out at eight stations in the upper Bandama: Five stations on the Lokpoho River (L1, L2, L3, L4 and L5) and three stations on the main stream of the Bandama River (M1, M2 and M3).This took place at the following periods: early dry season (EDS: October-November), full dry season (FDS: December-February), late dry season (LDS: March-May), early rainy season (ERS: June), full rainy season (FRS: July-August) and late rainy season (LRS: September). Chlorophyll concentration (Chl a) was calculated by stations during the different sampling campaigns. For this purpose one liter of water was taken per station to be filtered under pressure by a filter (Auto-filtre) in the laboratory. Before filtration in the laboratory, the samples are packaged in the field with aluminum foil and kept in a cooler cool and protected from light. The time between sampling and filtration did not exceed 12 hours

Immediately after filtration, the filter is deposited in $20 \mathrm{ml}$ of $90 \%$ acetone for $30 \mathrm{~min}$ to extract the chlorophyll [6]. Then the extract is brought to the centrifuge for 10 minute at 3000 revolutions/minute. For reading, $3 \mathrm{ml}$ of the extract was placed in a quartz tank of the spectrophotometer and the sample absorptions at $750 \mathrm{~nm}$ (to estimate turbidity) and at $665 \mathrm{~nm}$ were measured. After this reading, hydrochloric acid has been added directly into the tank, and the spectrometer can be taken for another reading at the same lengths mentioned previously. Note that the control was made with $90 \%$ acetone each time the wavelength was changed. The [7] calculation method was used to determine the chlorophyll concentration. This chlorophyll concentration, expressed in $\mu \mathrm{g} / \mathrm{L}$, in the analyzed water sample was calculated according to the following equation:

$$
\text { Chl a }(\mu \mathrm{g} / \mathrm{L})=27 \times\left[(\mathrm{A} 1665-\mathrm{A} 1750)-(\mathrm{A} 2 \text { 665-A2 750) }] \times \frac{v X L}{V} \quad\right. \text { where }
$$


A1 665 and A1 750 are respectively the absorbance's at $665 \mathrm{~nm}$ and $750 \mathrm{~nm}$ before acidification; A2 665 and A2 750 are respectively the absorbance's at $665 \mathrm{~nm}$ and $750 \mathrm{~nm}$ after acidification; $\mathrm{v}$ is the volume of initial solvent (in milliliters) used for extraction; $\mathrm{V}$ is the volume of filtered water (liters); $\mathrm{L}$ is the optical path of the tank used (centimeters).

\section{RESULT}

\subsection{Variations of Chlorophyll (Chl a) in the Lokpoho River}

In the dry season, the chlorophyll a concentration of the Lokpoho River ranges from 9.13 $\mu \mathrm{g} / \mathrm{L}$ (L5) to 17.95 $\mu \mathrm{g} / \mathrm{L}$ (L3). The average value is $12.88 \mu \mathrm{g} / \mathrm{L}$. There is no significant difference between chlorophyll a concentrations at stations in the dry season (Student t-test, p-value> 0.05) (Figure 2)

In the rainy season, chlorophyll a ranges from $16.67 \mu \mathrm{g} / \mathrm{L}$ (L5) to $29.41 \mu \mathrm{g} / \mathrm{L}$ (L3). The average value is $23.34 \mu \mathrm{g} / \mathrm{L}$. The chlorophyll a concentrations of the L3 and L5 stations are significantly different (Student t-test, p-value $<\mathbf{0 . 0 5})($ Figure 2 ).

At all stations of the Lokpoho River, chlorophyll concentration is higher in the rainy season than in the dry season. The average annual value is $17.82 \mu \mathrm{g} / \mathrm{L}$. The concentration of chlorophyll a is not significantly different at the same stations from one season to another (Student t-test, p-value> 0.05) (Figure 2).

Figure 3 shows the periodic variation of chlorophyll a. In the Lokpoho River, the maximum chlorophyll concentrations are recorded at the beginning of the rainy season (ERS $=23 \mu \mathrm{g} / \mathrm{L}$ ) and during the rainy season $(\mathrm{FRS}=27.33 \mu \mathrm{g} / \mathrm{L}$ ). The minimum is reached during the full dry season $(\mathrm{FDS}=6.05 \mu \mathrm{g} / \mathrm{L})$.

There is a significant difference between the concentration of chlorophyll a in the high dry season (FDS $=6.05 \mu \mathrm{g} / \mathrm{L})$ and those at the beginning of the dry season $(\mathrm{EDR}=21.81 \mu \mathrm{g} / \mathrm{L})$, from the beginning and the end of the rainy season $(\mathrm{ERS}=23 \mu \mathrm{g} / \mathrm{L}, \mathrm{LRS}=$ $9 \mu \mathrm{g} / \mathrm{L})$ (Student t-test, p-value <0.05).

The difference is also significant between the end of the dry season (LDS $=9 \mu \mathrm{g} / \mathrm{L}$ ) and the beginning and the full rainy season $(\mathrm{ERS}=23 \mu \mathrm{g} / \mathrm{L}, \mathrm{FRS}=27.33 \mu \mathrm{g} / \mathrm{L})$ (t-test Student, p-value <0.05). Also, the difference is significant between the full rainy season $(\mathrm{FRS}=27.33 \mu \mathrm{g} / \mathrm{L})$ and the full dry season $(\mathrm{FDS}=6.05 \mu \mathrm{g} / \mathrm{L})$ (Figure 3).

\subsection{Variation of Chlorophylla (Chl a) in the Bandama River}

In the Bandama River, chlorophyll ranges from $5.83 \mu \mathrm{g} / \mathrm{L}$ (M1) to $17.89 \mu \mathrm{g} / \mathrm{L}$ (M2) in the dry season, with an average value of $10.09 \mu \mathrm{g} / \mathrm{L}$. In the rainy season, it varies between $4.26 \mu \mathrm{g} / \mathrm{L}$ (M1) and $10.46 \mu \mathrm{g} / \mathrm{L}$ (M3), with a seasonal average of $8.04 \mu \mathrm{g} /$ L (Figure 2). Here the chlorophyll concentration of the dry season is greater than that of the rainy season. The average annual value is $9.07 \mu \mathrm{g} / \mathrm{L}$. Whatever the season, there is no significant difference between the chlorophyll concentrations of the Bandama River stations (Wilcoxon test, p-value> 0.05).

Depending on the period of the year, in the Bandama River, the end of the dry season (LDS $=17.98 \mu \mathrm{g} / \mathrm{L}$ ) has the highest chlorophyll a concentration, followed by the beginning of the rainy season (ERS $=9,3 \mu \mathrm{g} / \mathrm{L}$ ). The minimum value is obtained during the full dry season (FDS $=5.60 \mu \mathrm{g} / \mathrm{L}$ ). There is no significant difference between chlorophyll a concentrations at seasonal periods in the Bandama River (Student t-test, p-value> 0.05). The annual average value of chlorophyll a is $9.07 \mu \mathrm{g} / \mathrm{L}$ in the Bandama River.

The comparison of chlorophyll concentration between the Lokpoho River and the Bandama River shows that the chlorophyll concentration of the Lokpoho River is significantly different from that of the Bandama River in ERS, EDR, LRS and FRS (Student t test, $\mathbf{p}$-value $<\mathbf{0 . 0 5}$ ). The chlorophyll a is on average higher in Lokpoho River than the Bandama River

Globally, in the upper Bandama, the concentration of chlorophyll a is $11.84 \mu \mathrm{g} / \mathrm{L}$ in the dry season and $17.61 \mu \mathrm{g} / \mathrm{L}$ in the rain $\mathrm{g}$ season. The average annual value is $14.72 \mu \mathrm{g} / \mathrm{L}$ 


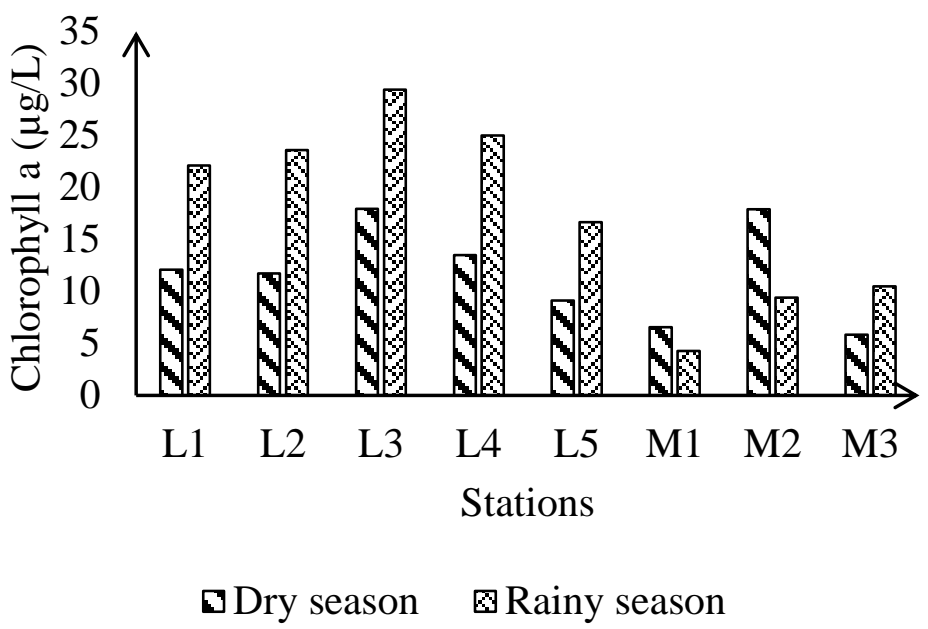

Figure 2 : Spatial variation of chlorophyll in dry season and rainy season in upper Bandama (Bandama River and Lokpoho River). SS: dry season; SP: rainy season. L1 to L5: stations of the Lokpoho River; M1 to M3: stations of the Bandama River.

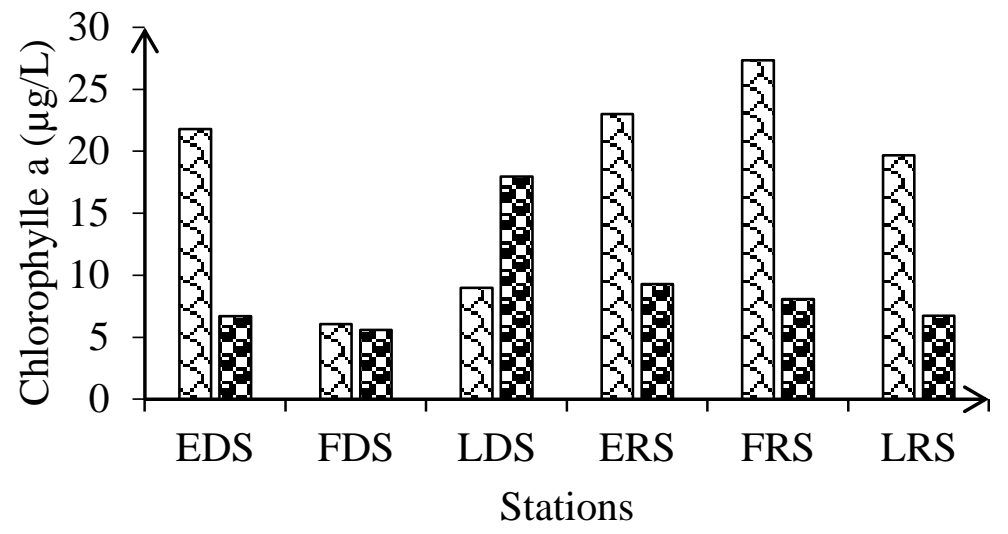

@Lokpoho River $\quad \boldsymbol{B}$ Bandama River

Figure 3: Periodic variations of chlorophyll in Bandama River and Lokpoho River. DSS: early dry season, PSS: full dry season, FSS: late dry season, DSP: early rainy season, PSP: full rainy season and FSP: late rainy season.

\section{DISCUSSIONS}

Chlorophyll a ( $\mathrm{Chl} \mathrm{a)} \mathrm{measurement} \mathrm{was} \mathrm{used} \mathrm{as} \mathrm{an} \mathrm{indicator} \mathrm{of} \mathrm{phytoplankton} \mathrm{biomass} \mathrm{in} \mathrm{natural} \mathrm{waters.} \mathrm{It} \mathrm{is} \mathrm{the} \mathrm{most} \mathrm{important}$ pigment in aerobic photosynthetic organisms (excluding cyanobacteria) and all algae contain them [8]. Thus, its variation is essential in studies of water quality and variations of nutrients for the monitoring of rivers

The chlorophyll a concentrations obtained in this study are comparable to those of some authors who studied in the Bandama basin. Indeed, the annual average value of chlorophyll in the Lokpoho River is higher than the concentrations obtained by [9] on Bandama (4.36 mg/m3 at Fétékro, $4.69 \mathrm{mg} / \mathrm{L}$ at the top of Katiola, [10] (10.7 $\mu \mathrm{g} / \mathrm{L})$ in Lake Kossou and [11] (fluvial part=10.09 $\mu \mathrm{g} / \mathrm{L}$, lakes Kossou and Taabo $=12.46 \mu \mathrm{g} / \mathrm{L}$ ) in the Bandama River. On the contrary, the concentration of chlorophyll a in the northern Bandama River $(9.07 \mu \mathrm{g} / \mathrm{L})$ is lower or equal to those of the authors cited above mentioned authors, except [9].

In the upper Bandama, the concentration of chlorophyll a is higher in the rainy season (especially during the rainy season) than in the dry season. This is the case for the Lokpoho River, but the opposite for the Bandama River. Indeed, rainwater runoff from the streets and agrosystems of the town of Ferkessédougou is said to be at the origin of the high concentration of nutrient salts [12, 13] in the Lokpoho River during the rainy season. This phenomenon, combined with the increase in dissolved oxygen, contributes to lowering the $\mathrm{pH}$ of the water $(\mathrm{pH}<7)$, favoring, according to [14] the development of algae. Hence an increase in the concentration 
of chlorophyll a in the rainy season. At the Bandama River, the increase in nutrient salt concentration during the dry season is due to industrial activities in the region

The concentration of chlorophyll a is higher in the Lokpoho River $(17,82 \mu \mathrm{g} / \mathrm{L})$ than in the Bandama River $(9,07 \mu \mathrm{g} / \mathrm{L})$. This result reflects the higher nutrient salt in the Lokpoho River than in the Bandama River. L2 and L3 stations of Lokpoho River are receptacles for runoff from the city of Ferkessédougou and agrosystems around the city. The uncontrolled use of fertilizers by farmers in these agrosystems causes the enrichment of the river Lokpoho during the fluvial period. At the level of the Bandama River, it receives the streams of the Sucaf-CI zone. Unlike the Lokpoho River, these runoffs are less loaded with nutrient salt of agricultural origin. In fact, the agricultural parcels of Sucaf-CI do not let out agricultural inputs even after a heavy rain. As a result, dam of about $60 \mathrm{~cm}$ high are erected around the parcels. This agricultural behavior, beneficial, should be encouraged near the farmers of the region to protect the aquatic resources of the Savannah region, for a better valuation of them.

\section{CONCLUSION}

The periodic monitoring of chlorophyll in the upper Bandama allowed to analyze the seasonal variations of the chlorophyll and to better understand certain functional particularities. The concentration of Chlorophyll in the upper Bandama is higher in the rainy season than in the dry season, especially during the rainy season (PSP). This increase in the rainy season is linked to the runoff loaded with nutritive salt from the town of Ferkessédougou and various agrosystems. The Lokpoho River records the highest values of Chlorophyll in the upper Bandama. This river should be monitored because of its high chlorophyll content which corroborates a rich high in nutrient salt

\section{ACKNOWLEDGEMENTS}

The authors wish to thank Hydrobiology laboratory of Felix Houphouet-Boigny University and Sucaf-Ci for creating an enabling environment for this research work. We also thank Mr. PAUL Jamoulle Adrien for his contribution.

\section{BIBLIOGRAPHIC REFERENCES}

[1] Gohin,F. et L'Helguen S., 2012. État physique et chimique, caractéristiques chimiques, répartition spatio-temporelle de la chlorophylle $a$. Rapport Ifremer, 12p.

[2] Chaouachi B., BEN HASSINE O.K. et Lemoalle J., 2001. Variations des teneurs en chlorophylle $a$ et en sels nutritifs dans la lagune de l' ichkeul. Bull. Inst. Natn. Scien. Tech. Mer de Salammbô, Vol. 28,

[3] Lévêque C., Dejoux C. et Iltis A., 1983. Limnologie du fleuve Bandama, Côte d'Ivoire. Hydrobiologia, 100 :113-141

[4] Guillaumet J. L. et Adjanohoun E., 1971. La végétation. in : "Le milieu naturel de Côte d'Ivoire". Mém. ORSTOM, Paris, n50:161-262

[5] Péné C.B. et Kehé M., 2005. Performances de trois variétés de canne à sucre et rationnement hydrique en prematuration au nord de la cote d'ivoire. Agronomie Africaine, 17 (1) : 7-18.

[6] AFNOR NF T 90-117, 1999. Qualité de l'eau, Dosage de la chlorophylle a et d'un indice phéopigments - Méthode par spectrométrie d'absorption moléculaire. AFNOR 11 p.

[7] Lorenzen C.J., 1967. Vertical distribution of chlorophyll and phaeo-pigments: Baja California. Deep-Sea Research, 1967, Vol. 14 , pp. 735 to 745

[8] Hébert, S. et Légaré S., 2000. Suivi de la qualité des rivières et petits cours d'eau, Québec, Direction du suivi de l'état de l'environnement, ministère de l'Environnement, envirodoq no ENV-2001-0141, rapport n QE-123, 24 p.

[9] Iltis A., 1982. Peuplements algaux des rivières de Côte d'ivoire. Rev. Hydrobiol. Trop. 15 (3): 231-239

[10] Groga N., 2012. Structure, fonctionnement et dynamique du phytoplancton dans le lac de Taabo (Côte d'Ivoire) Thèse de doctorat de l'université de Toulouse $224 \mathrm{p}$

[11] Lozo R.N., 2016. Composition floristique et distribution des peuplements de micro-algues du fleuve Bandama. Thèse de Doctorat, Université Félix Houphouët-Boigny, Abidjan, Côte d'Ivoire, $161 \mathrm{p}$ 
[12] Dufour, P. et Durand, J. R., 1982 La production végétale des lagunes de Côte d'Ivoire. Rev. Hydrobiol. trop. 15 (3) : 209 230

[13] Biggs B. J. F., 2000. Eutrophication of streams and rivers: dissolved nutrient-chlorophyll relationships for benthic algae. $J$. $N$. Am. Benthol. Soc., 19(1):17-31.

[14] Dia A. et Reynaud P.A. 1982. Le phytoplancton du lac de Guiers : approche qualitative et quantitative. Cah. ORSTOM, sér. Biol. 45: 35-47. 